\title{
Field comparison of sardine post-flexion larval growth and biochemical composition from three sites in the W Mediterranean (Ebro river coast, bays of Almería and Málaga)
}

\author{
ALBERTO GARCÍA ${ }^{1}$, DOLORES CORTES ${ }^{1}$, TEODORO RAMÍREZ ${ }^{1}$, \\ CASTOR GUISANDE ${ }^{2}$, JOSÉ QUINTANILLA ${ }^{1}$, FRANCISCO ALEMANY ${ }^{3}$, \\ JOSÉ MARÍA RODRÍGUEZ ${ }^{4}$, JUAN P. ÁLVAREZ ${ }^{1}$ and ÁNGEL CARPENA ${ }^{1}$ \\ ${ }^{1}$ Instituto Español de Oceanografía, Aptdo. 285, 29640 Fuengirola, Málaga, Spain. E-mail: agarcia@ma.ieo.es \\ ${ }^{2}$ Universidad de Vigo, Facultad de Ciencias, Dept ${ }^{\circ}$ de Ecología y Biología Animal, \\ Lagoas Marcosende, 36200 Pontevedra, Spain \\ ${ }^{3}$ Instituto Español de Oceanografía, Muelle Pelaires, Palma de Mallorca, Spain \\ ${ }^{4}$ Instituto Español de Oceanografía (Gijón, Asturias)
}

SUMMARY: Late larval stages of sardine $(16-23 \mathrm{~mm})$ were sampled during the 2003 spawning season in their nursery grounds located off the Ebro river mouth, on the Catalan coast, and in two bays of the Alborán Sea coasts, the Bay of Almería and the Bay of Málaga. The daily growth analysis of each sampled population revealed faster growth in the Ebro sardine larvae than in both of the Alboran Sea larval populations. This fact is supported by their greater content with age of DNA, RNA and protein. However, the significantly higher carbohydrate content of the Bay of Almería sardine larvae and a higher Fulton's index, indicative of energy storage of individuals, in both of the sardine populations sampled in the Bays of Almería and Málaga show evident differences in the daily growth of the Alborán Sea larvae from those originating in the Ebro region. Late larval growth in the Alborán Sea sardine tends to favour an increase in body mass rather than in body length. This study hypothesises that the productivity pulses off the Alboran Sea coasts induced by the north and northwestern wind regimes may be responsible for the growth pulses observed in the otolith microstructure.

Keywords: sardine larvae, Mediterranean, growth, DNA, RNA, proteins, carbohydrates.

RESUMEN: CRECIMIENTO Y CONTENIDO BIOQUÍMICO COMPARATIVO DE LARVAS EN POSTFLEXIÓN DE SARDINA DE TRES ZONAS DEl Mediterráneo Occidental (EBro, BAHÍAs de Almaría y MálagA). - Estados avanzados de larvas de sardina (de 16 a $23 \mathrm{~mm}$ ) fueron muestreados durante el invierno de 2003 en zonas de alevinaje situadas en la desembocadura del río Ebro, en la costa catalana, y en las bahías de Almería y de Málaga, en las costas del Mar de Alborán. El análisis del crecimiento diario de cada población larvaria muestreada, evidencia un mayor crecimiento en las larvas procedentes del Ebro respecto a las nacidas en el Mar de Alborán. Esta observación se corrobora con un mayor incremento con la edad de los contenidos en DNA, RNA y proteínas de la población larvaria de sardina del río Ebro. Sin embargo, un contenido significativamente mayor de carbohidratos en la población de Almería, así como un mayor índice de Fulton, indicador de energía almacenada en un individuo, en ambas poblaciones del Mar de Alborán, evidencia una estrategia diferenciada de crecimiento de estas poblaciones larvarias con respecto a las procedentes del río Ebro. En consecuencia, las larvas de sardina del Mar de Alborán muestran una tendencia a crecer más en masa que en longitud, como lo evidencia el crecimiento relativo del peso seco, DNA, RNA y proteínas en relación con su longitud estándar. En este estudio se plantea la hipótesis de que los pulsos productivos en el Mar de Alborán, inducidos por el régimen de vientos de norte y poniente, pueden ser responsables de los pulsos de crecimiento larvario, como se evidencia en las microestructuras de los otolitos.

Palabras clave: sardina, larvas, Mediterráneo, crecimiento, DNA, RNA, proteínas, carbohidratos. 


\section{INTRODUCTION}

Among the small pelagic resources distributed over the Spanish Mediterranean coasts, sardine (Sardina pilchardus) is the most abundant. Its protracted spawning season, from autumn to spring, peaking in winter (January-February) (GómezLarrañeta, 1960; Rodríguez, 1990; Palomera and Olivar, 1996; Olivar et al., 2001, 2003) contributes to its greater abundance in comparison with other small pelagic resources such as anchovy and gilt sardine. Although the species is distributed all along the Spanish Mediterranean shelf, the main bulk of the stock is located in the northwestern Mediterranean, off the Catalan coasts and in the Gulf of Lions and the Alborán Sea (Abad et al., 1998). The temporal series of acoustic evaluations by the ECOMED project shows that the Alborán Sea sardine population is separated from the northern sardine populations by the Gulf of Vera, northeast of Alborán (Giráldez, pers. comm.).

The analysis of larval growth in early life stages of species is fundamental to fisheries science, as small changes in these growth rates can lead to strong recruitment variations (Houde, 1987). Recruitment dynamics appear to be linked to the growth-mortality hypothesis (Anderson, 1988), by which three concepts or mechanisms may be specified: the "bigger is better" hypothesis, the "growth rate" hypothesis and the "stage duration" hypotheses (Hare and Cowen, 1997). All these functional hypotheses are related to optimal growth, since faster growth rates lead to larger individuals who are less prone to mortality than smaller individuals (Miller et al., 1988) or decrease stage duration during the developmental early life stages and therefore exposure to predation (Folkvord and Hunter, 1986). Therefore, the study of growth of advanced larval stages of small pelagics, such as sardines and anchovies, may offer certain advantages. Largersized larvae have a longer time span registered in their otoliths, show lower mortality rates than the earlier life stages (Butler, 1991) and due to their proximity to recruitment may show a greater potential for predicting recruitment than the younger stages (Peterman et al., 1988; Bradford, 1992).

The larvae that form part of this study are categorised as advanced stages of post-flexion larvae, bearing in mind that the process of urostyle flexion occurs at 11-12.5 mm and the formation of the gas bladder at $13 \mathrm{~mm}$ (Ré, 1986). At $20 \mathrm{~mm}$, the forma- tion of pelvic fin is completed and at $40 \mathrm{~mm}$ the process of metamorphosis to juvenile begins (Fage, 1920; Ré, 1986). These late larval stages constitute target species of many fry fisheries that occur in many areas of the Mediterranean.

The sampling of these larval stages is easy thanks to the existence of traditional fry fisheries off the Alborán Sea coasts exploiting advanced larval stages of sardine and anchovy with a good knowledge of their fishing grounds (García et al., 1981). The practice was common until the mid-eighties when a ban on this type of fishery was implemented. It is not exclusive to the Alborán Sea. The "bianchetto" fishery in the Ligurian, Ionian and Adriatic Seas (Ungaro et al., 1994; Romanelli et al., 1994, 1998) and the "shirasu" fishery off the Japanese coasts represent similar examples of fry fisheries mainly exploiting advanced larval stages of sardines and anchovies. Research on the "shirasu" fishery has often been used to assess the state of small pelagic resources off the coasts of Japan (Kishida et al., 1994; Suda and Kishida, 1997).

Growth is the consequence of a nutritional status resulting from the surrounding biotic and abiotic environmental conditions experienced by an individual, besides the inherent parental genetic traits, as observed in North Sea herring (Høie et al., 1999). Therefore, to understand the dynamics of the sardine resource distributed off the Spanish Mediterranean coast, one cannot overlook the different environmental features characterising each region that influence a particular growth strategy of the species.

The northwestern Mediterranean sector (Catalan Sea) displays a sardine spawning habitat that contrasts sharply with that of the southwestern Mediterranean sector (Alborán Sea). Due to the major river runoffs off the Catalan coasts, in particular the Ebro River in the south, the Catalan shelf is much wider than the Alborán shelf. The continental shelf under the influence of Ebro river runoff is an important sardine spawning ground (Olivar et al., 2001). The expansion of the shelf in this area may cause intrusions of oceanic water onto the shelf, thereby producing upwelling in the area (Font et al., 1990). Off the shelf break, the hydrographic circulation is characterised by a shelf-slope jet (Catalán current) that flows southwest (Castellón et al., 1990), which is in geostrophic balance with a typical shelf-slope density front (Font et al., 1988). According to Salat et al. (2002), the fertilisation of the Catalan shelf waters during the winter is caused 
by mixing of the water column and intrusions of slope waters.

Another source of enrichment of the surface layers is the effect of the NW Mistral or the N Tramontana wind regimes, especially during winter when sardine shows its highest spawning peak. If persistent, these winds cause coastal upwellings in localised areas such as the Gulf of Lions and off the Ebro river outflow (Millot, 1990; Estrada, 1996; Salat et al., 2002). Lloret et al. (2004) highlighted the importance of wind regime on sardine recruitment, finding that $19 \%$ of the variance of sardine landings was explained by variance of wind mixing index, with a time lag of 18 months.

In contrast, the northern coast of the Alborán Sea has a narrow shelf (from the Bay of Málaga to the Bay of Almería it represents $10 \%$ of the shelf area of the total Catalonian shelf, as determined by the area coverage estimates of the Mediterranean ECOMED acoustic surveys, whose offshore boundary is the $200 \mathrm{~m}$ isobath). Its coastal hydrography is strongly influenced by Atlantic water masses in its upper layers. Two main sources of upwelling occur in this basin: periodic wind-induced upwellings, mostly occurring near the northern coasts of the Alborán Sea, and gyre-induced upwelling, which takes place at the boundaries of the anticyclonic gyres (Sarhan et al., 2000; García-Gorritz and Carr, 2001).
The predominant wind regime, the westerlies (ponientes), tend to induce upwelling, thereby producing an offshore directed transport along the northern coasts (Bakun and Agostini, 2001) of the Alborán Sea. A series of bays, extending from the Bay of Marbella to the Bay of Almería, comprise a series of sardine and anchovy nursery grounds, among which the Bay of Málaga is the most important in terms of larval abundance (García et al., 1988).

In consequence, this study aims to analyse the late larval growth strategies of sardine and their nutritional condition as measured from nucleic acid, protein and carbohydrate contents from three selected sites subject to contrasting environmental conditions: off the Ebro River and in the Bays of Almería and Málaga.

\section{MATERIALS AND METHODS}

The samples and data for this work were collected on board the $R / V$ Cornide de Saavedra from November 17 to December 19, 2003 jointly with the annual ECOMED-1103 acoustic survey for the biomass estimation of small pelagics along the Spanish Mediterranean coasts. To select optimal sites for sampling advanced sardine larval stages, standard bongo 60 oblique tows ( $200 \mathrm{~mm}$ mesh) were carried

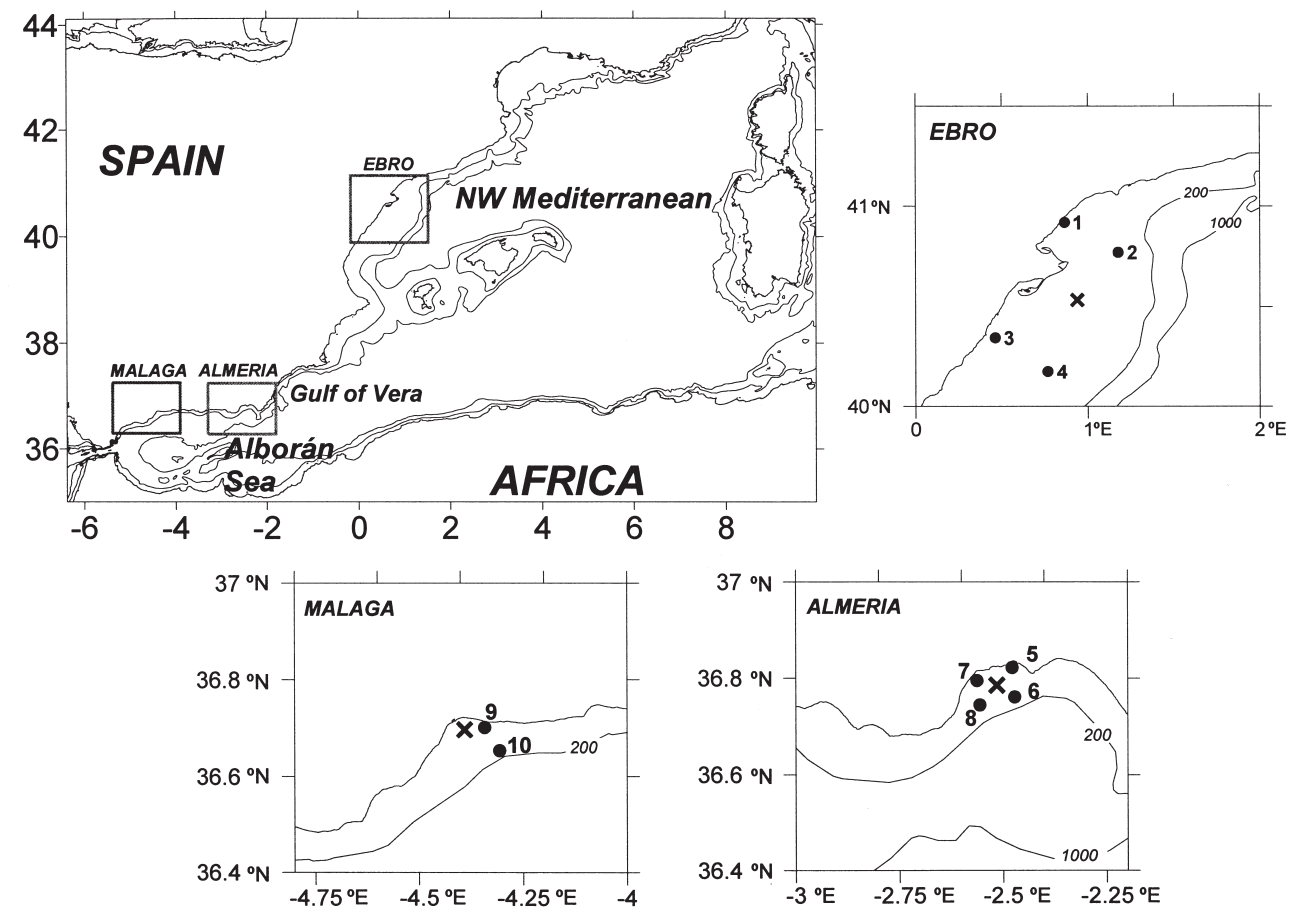

FIG. 1. - Geographical location of sardine larval sampling sites off the Ebro river mouth and in the Bays of Almería and Malaga (x). Numbered dot stations correspond to microzooplankton and CTD stations. 
TABLE 1. - Date, geographical location, and bottom depth of each sardine larval sampling site.

\begin{tabular}{lcccc}
\hline Site & Sampling date & Latitude & Longitude & Depth (m) \\
\hline Ebro & $3 / 12 / 2003$ & $40^{\circ} 46^{\prime} 23 \mathrm{~N}$ & $0^{\circ} 54^{\prime} 25 \mathrm{E}$ & 50 \\
Almería & $15 / 12 / 2003$ & $36^{\circ} 46^{\prime} 81 \mathrm{~N}$ & $2^{\circ} 30^{\prime} 90 \mathrm{~W}$ & 50 \\
Málaga & $18 / 12 / 2003$ & $36^{\circ} 42^{\prime} 35 \mathrm{~N}$ & $4^{\circ} 23^{\prime} 24 \mathrm{~W}$ & 40 \\
\hline
\end{tabular}

out on the shelf along a set of transects quasi-parallel to the coastline off the Catalonian coast and in the northern Alborán Sea. Bongo 60 plankton samples were briefly examined for sardine larval abundance before a site was selected for sampling advanced larval stages. The location of these sampling sites is shown in Table 1 and Figure 1.

At each of these stations, Seabird 25 CTD casts were carried out and microzooplankton samples were collected by means of vertical tows to a maximum depth of $70 \mathrm{~m}$, wherever possible with a CalVET frame geared to a $50 \mathrm{~mm}$ mesh net. The microzooplankton samples were sieved on board in order to separate the mesozooplanktonic and microzooplanktonic fractions. The microzooplankton fraction (50$200 \mathrm{~mm}$ ) was stored frozen in an eppendorf vial.

For this comparative study of sardine larval growth strategies from the three sites in which advanced larval stages were present (the Ebro river area and the Bays of Almería and Málaga), only the environmental data collected from the stations surrounding the sites at which sardine larvae were sampled were considered as representative of the larval habitat conditions (Fig. 1).

\section{On board larval sampling procedures}

In the sites selected for larval sampling off the Ebro River outflow and in the Bays of Almería and Málaga (Fig. 1 and Table 1), sardine larvae were collected at night time by means of a bongo gear of square aperture measuring $1 \mathrm{~m}$ diagonally, equipped with a black tinted net of $1 \mathrm{~mm}$ mesh size to reduce avoidance of the net. The number of surface tows for collecting sardine larvae at each site was samplesize dependent. Tow duration was fixed to $10 \mathrm{~min}-$ utes to prevent damage to larva at a speed of 2 knots. Larvae were sorted and conserved in liquid nitrogen.

\section{Laboratory analysis procedures}

Before otolith extraction, the frozen sardine larvae were thawed to ambient temperature. Defrosted larvae were then measured to standard length (SL) by means of an image analysis program (NIH Image). A representative sample of advanced postflexion larval stages ranging from 16 to $23 \mathrm{~mm}$ (Fig. 2) from each site sample was selected for the joint analysis of age estimation and the nutritional condition analysis.

After the selected range of larvae had been measured, they were dehydrated in a dry freezer for 24 hours. Post-flexion larvae were then dry weighed on a precision balance $(1 \mathrm{mg})$. To estimate Fulton's condition factor, indicative of energy storage in individuals, SL and dry weight (DW) of individual larvae were used $\left(\left(\mathrm{DW} / \mathrm{SL}^{3}\right)^{*} 1000\right)$.

After dry weighing, larvae were re-hydrated with distilled water. The otoliths were then extracted by means of fine needles and dropped onto a slide and cleansed with a drop of distilled water. After drying, the sagittae were fixed to the slide by nail lacquer.

The sagittae were read using the OTO program (Andersen and Moksness, 1988), as described in García et al. (2003). All the sagitta measurements (counts, widths, radius) were done at 1000x magnification. Differences in growth between areas were tested by ANCOVA normalised to log linear data, using Ln age as a covariant, or Ln SL in the case of relative growth. Statistical analysis was carried out at a significance level of $\alpha=0.05$.

After otolith extraction, individual sardine larvae were homogenised by means of ultrasonic pulses $(2 \times 10 \mathrm{~s})$ at $0^{\circ} \mathrm{C}$ in $700 \mathrm{ml}$ of Tris-buffer $(0.05 \mathrm{M}$ Tris, $0.1 \mathrm{M} \mathrm{NaCl}, 0.01 \mathrm{M}$ EDTA, pH 8.0) containing SDS $0.01 \%$ (final concentration). The homogenate was centrifuged at $6000 \mathrm{rpm}$ for $8 \mathrm{~min}$ at $4^{\circ} \mathrm{C}$. The DNA concentration in the supernatant was determined by fluorescence after incubation of one aliquot $(100 \mathrm{ml})$ with $0.02 \mathrm{mg} / \mathrm{ml} \mathrm{RNAase} \mathrm{(final}$ concentration) at $37^{\circ} \mathrm{C}$ for $30 \mathrm{~min}$. A second aliquot of supernatant $(100 \mathrm{ml})$ was transferred to another vial for total nucleic acid (RNA+DNA) determination. The fluorescent dye ethidium bromide was used for quantification of nucleic acids. Fluorescence of samples was measured at $\lambda$ exc: 360 $\mathrm{nm}, \lambda \mathrm{em}$ : $590 \mathrm{~nm}$ against a blank. Calibration curves were made with DNA Type I from calf thymus and RNA Type III from baker's yeast (all from SIGMA). The standard curves slopes ratio of RNA/DNA was between 0.400-0.405 (mean=0.402; $\mathrm{sd}=0.0025)$. Detailed information on analytical procedures is provided in Belchier et al. (2004). Protein content (PROT) in the supernatant was determined 
in $200 \mathrm{ml}$ aliquots following the method of Lowry et al., (1951). The method of Dubois et al. (1956) was used for carbohydrate determination.

Microzooplankton was analysed after drying the samples in an electric oven to a constant weight at $60^{\circ} \mathrm{C}$ (Rao and Krupanidhi, 2001; Rao and Kumari, 2002). Samples were weighed to the nearest $0.1 \mathrm{mg}$. Subsequently, each sample was homogenised at $0^{\circ} \mathrm{C}$ in $1 \mathrm{ml}$ of Tris-buffer (0.05 M Tris, $0.1 \mathrm{M} \mathrm{NaCl}, 0.01$ M EDTA, adjusted to $\mathrm{pH} 8.0$ with $\mathrm{HCl}$ ) by means of ultrasonic pulses ( $2 \times 10 \mathrm{~s}$ ). Afterwards, $15 \mu 1$ sodium dodecyl sulphate SDS $(0.7 \%)$ was added to the homogenate. The homogenate was centrifuged at $6000 \mathrm{rpm}$ for $8 \mathrm{~min}$, at $4^{\circ} \mathrm{C}$. The supernatant was fractionated in two aliquots, with $50 \mu 1$ taken for protein analysis and $50 \mu 1$ for carbohydrates analysis. Protein and carbohydrate content was determined by the methods of Lowry et al. (1951) and Dubois et al. (1956), respectively.

\section{RESULTS}

Advanced sardine post-flexion larval stages from the three sites ranged from 16-23 mm (Fig. 2). The size frequency distribution followed normal SL distributions along SL means of $19.8 \mathrm{~mm}$ $(\mathrm{stdv}=1.5), 20.0 \mathrm{~mm}(\mathrm{stdv}=1.6)$ and $19.7 \mathrm{~mm}$ (stdv= 0.4) for the Ebro, Bay of Almería and Bay of Málaga sardine larval populations, respectively. Mean SL did not show significant differences between the populations $(p>0.05)$. The average ages of the analysed sardine larvae from the Ebro, Bay of Almería and Bay of Málaga were 24.2, 29.7 and 29.2 days, respectively.

\section{Larval habitat conditions}

The temperature (T) and salinity (S) at $10 \mathrm{~m}$ depth, the microzooplankton dry weight and the protein (PROT) and carbohydrate (CHO) content from each site are shown in Table 2. Significant differences $(p<0.05)$ are observed in respect to the hydro-

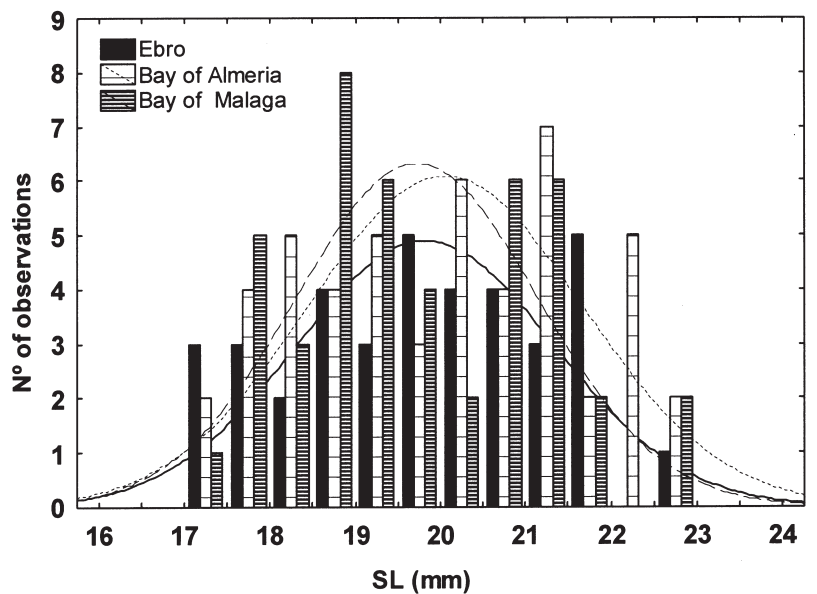

FIG. 2. - Size (SL) frequency distribution of analysed sardine larvae off the Ebro river mouth and in the Bays of Almería and Málaga.

graphic variables (T and S) between the Alborán Sea sites (Bays of Almería and Málaga) and the Ebro River area. The highest temperatures were observed in the Alborán Sea sites, particularly in the Bay of Almería, while the lowest temperature occurred off the Ebro river region. Nonetheless, the temperature difference between the areas was slightly below $1^{\circ} \mathrm{C}$. The Atlantic influence on the coast of Málaga is shown in the minimum salinity values.

Regarding the microzooplankton biomass values and their corresponding PROT and $\mathrm{CHO}$ content (Fig. 3), no significant differences were

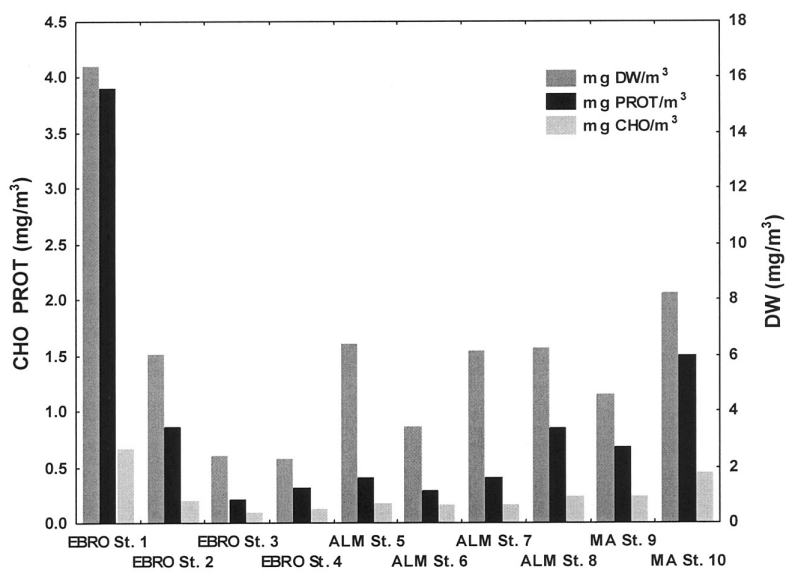

FIG. 3. - Microzooplankton biomass values expressed in DW, PROT and $\mathrm{CHO}$ content by station.

TABLE 2. - Average environmental data collected at the sampled stations of each site.

\begin{tabular}{|c|c|c|c|c|c|c|c|c|c|c|}
\hline \multirow[t]{2}{*}{ Site } & \multicolumn{2}{|c|}{$\mathrm{T}\left({ }^{\circ} \mathrm{C}\right)$} & \multicolumn{2}{|c|}{ SAL (p.s.u.) } & \multicolumn{2}{|c|}{ DW (mg/m³) } & \multicolumn{2}{|c|}{ PROT $\left(\mathrm{mg} / \mathrm{m}^{3}\right)$} & \multicolumn{2}{|c|}{$\mathrm{CHO}\left(\mathrm{mg} / \mathrm{m}^{3}\right)$} \\
\hline & Mean & SD & Mean & SD & Mean & SD & Mean & SD & Mean & SD \\
\hline Ebro & 15.941 & 0.177 & 37.648 & 0.295 & 6.76 & 6.647 & 1.32 & 1.747 & 0.27 & 0.270 \\
\hline Almería & 16.824 & 0.227 & 37.789 & 0.076 & 5.55 & 1.401 & 0.48 & 0.245 & 0.18 & 0.041 \\
\hline Málaga & 16.402 & 0.287 & 36.461 & 0.044 & 6.41 & 2.570 & 1.09 & 0.573 & 0.34 & 0.146 \\
\hline
\end{tabular}




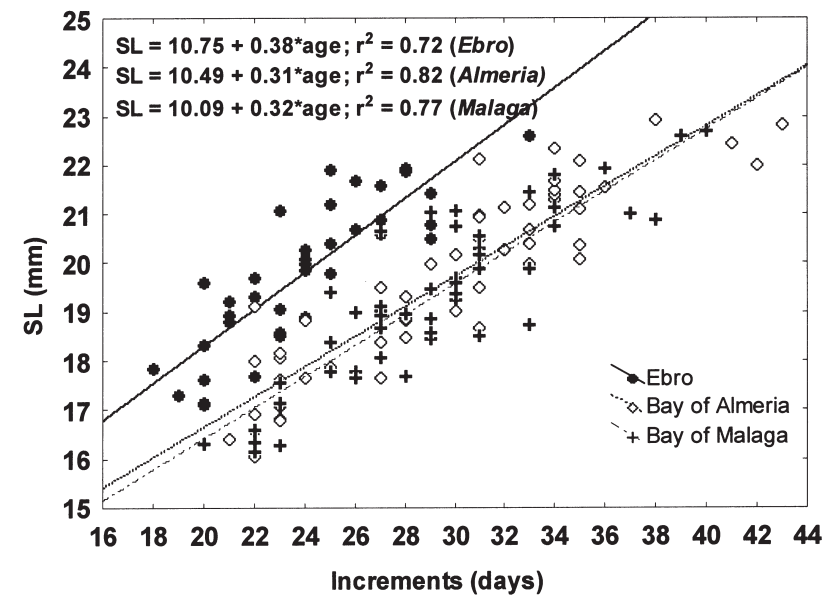

FIG. 4. - Standard length of sardine larvae (SL) vs age sampled at the different sites off the Mediterranean coast.

observed between sites due to the high variability of the data. Nevertheless, the influence of the Ebro River runoff was evident. The station off the river mouth recorded the highest microzooplankton DW and PROT content of all the stations sampled for microzooplankton. Inversely, south of the Ebro microzooplankton stations showed the lowest microzooplankton DW values overall. The microzooplankton stations in the Bays of Almería and Málaga showed on average more similar values between them.

\section{Somatic and otolith growth vs age}

Within the considered size range of late larval stages $(16-23 \mathrm{~mm})$, daily growth followed linear relationships (Fig. 4). Body size expressed by SL shows that the population sampled off the Ebro river mouth grew significantly faster (ANCOVA, $\left.\mathrm{F}_{2,139}=83.892, \mathrm{p}<0.001\right)$. On average, there was a difference of $2 \mathrm{~mm}$ per estimated age between this population and those from the Alborán Sea. However, no significant differences were observed

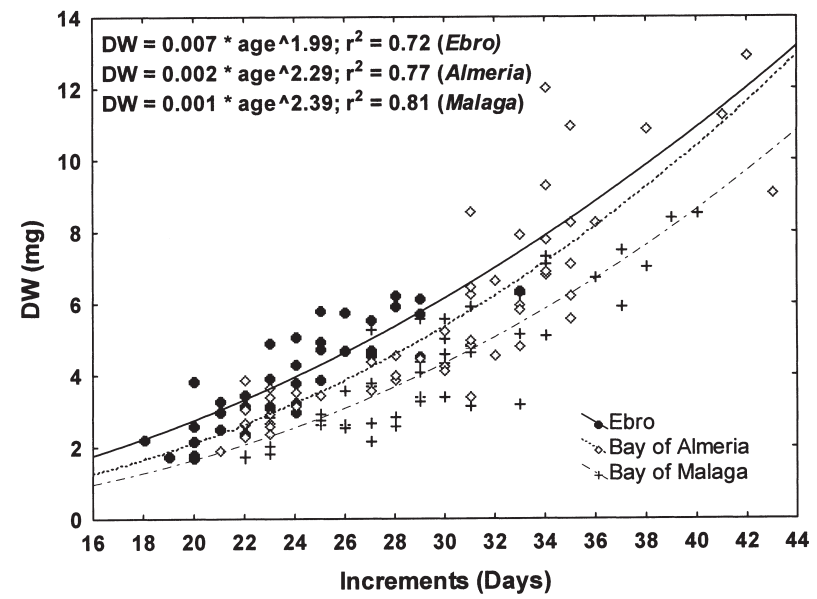

FIG. 5. - Dry weight of sardine larvae (DW) vs age sampled at the different sites off the Mediterranean coast.

in SL vs age between the Bay of Almería and Bay of Málaga larval populations (ANCOVA, $\mathrm{F}_{1,103}=$ $1.4840, \mathrm{p}>0.05)$.

Table 3 provides the somatic growth functions of each larval population expressed by DW and the biochemical constituents analysed. Daily growth expressed by the DW vs age relationship shows that each larval population is significantly different (ANCOVA, $\mathrm{F}_{2,139}=43.015$, $\mathrm{p}<0.001$ ). The Ebro population showed the highest DW increase, followed by the Bay of Almería and the Bay of Málaga populations, which likewise showed significant differences between them (ANCOVA, $\mathrm{F}_{1,103}=32.429$, $\mathrm{p}<0.001$ ) (Fig. 5). Moreover, the exclusion of five larvae belonging to the Almería larval population that showed rather high DW values (over $10 \mathrm{mg}$ ) did not alter the significant differences observed between each larval population. Similarly, DNA content showed a potential increase with age. The Ebro larval population showed significantly higher DNA content (ANCOVA, $\mathrm{F}_{2,131}=36.805, \mathrm{p}<0.0001$ ), followed by those of Almería and Málaga, respectively, which also showed significant differences

TABLE 3. - Somatic growth models expressed as DNA, RNA, PROT and CHO relationship with age by site of each sardine larval population.

\begin{tabular}{|c|c|c|c|}
\hline Variable & Ebro & $\begin{array}{l}\text { Somatic Growth Models } \\
\text { Almería }\end{array}$ & Málaga \\
\hline DNA $(\mu \mathrm{g})$ & $\begin{array}{l}\text { DNA }=(0.0844) * a g e^{\wedge}(1.734) \\
\mathrm{r}^{2}=0.62\end{array}$ & $\begin{array}{l}\text { DNA }=(0.0277) * \operatorname{age}^{\wedge}(2.022) \\
\mathrm{r}^{2}=0.84\end{array}$ & $\begin{array}{l}\text { DNA }=(0.037328) * \operatorname{age}^{\wedge}(1.879) \\
\mathrm{r}^{2}=0.76\end{array}$ \\
\hline RNA $(\mu \mathrm{g})$ & $\begin{array}{l}\text { RNA }=(0.2672) * \operatorname{age}^{\wedge}(1.768) \\
\mathrm{r}^{2}=0.53\end{array}$ & $\begin{array}{l}\mathrm{RNA}=(0.0725)^{*} \operatorname{age}^{\wedge}(2.087) \\
\mathrm{r}^{2}=0.77\end{array}$ & $\begin{array}{l}\mathrm{RNA}=(0.057414) * \operatorname{age}^{\wedge}(2.098) \\
\mathrm{r}^{2}=0.70\end{array}$ \\
\hline PROT $(\mu \mathrm{g})$ & $\begin{array}{l}\text { PROT }=(11.58) * \operatorname{age}^{\wedge}(1.473) \\
\mathrm{r}^{2}=0.38\end{array}$ & $\begin{array}{l}\text { PROT }=(0.8327) * \operatorname{age}^{\wedge}(2.179) \\
r^{2}=0.74\end{array}$ & $\begin{array}{l}\text { PROT }=(2.090) * \operatorname{age}^{\wedge}(1.905) \\
\mathrm{r}^{2}=0.63\end{array}$ \\
\hline $\mathrm{CHO}(\mu \mathrm{g})$ & $\underset{\mathrm{r}^{2}=0.62}{\mathrm{CHO}}=(0.270 \mathrm{e}-3) * \operatorname{age}^{\wedge}(1.849)$ & $\begin{array}{l}\mathrm{CHO}=(0.001245) * \operatorname{age}^{\wedge}(1.471) \\
\mathrm{r}^{2}=0.66\end{array}$ & $\begin{array}{l}\mathrm{CHO}=(0.249 \mathrm{e}-4) * \operatorname{age}^{\wedge}(2.431) \\
\mathrm{r}^{2}=0.69\end{array}$ \\
\hline
\end{tabular}




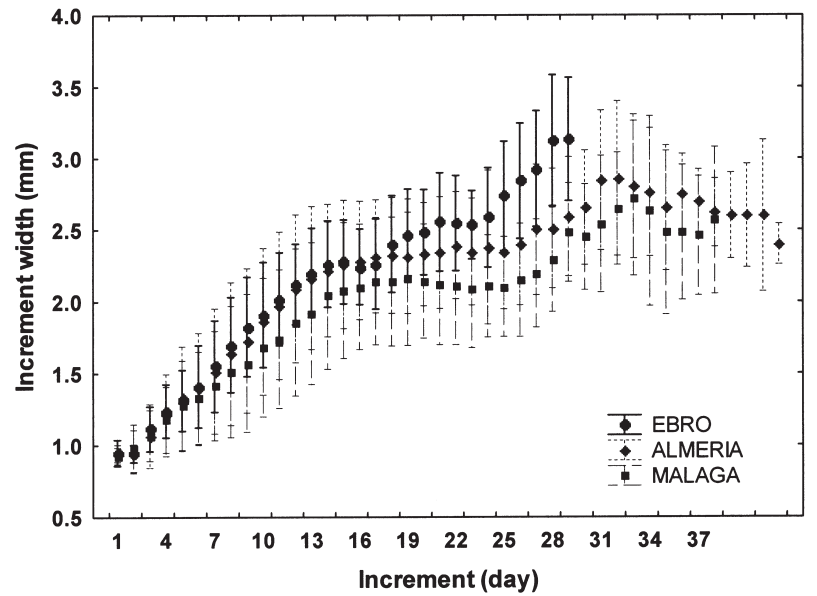

FIG. 6. - Average increment width of each sardine larval population vs increments at the sampled sites. Bars indicate standard deviation.

between them (ANCOVA, $\mathrm{F}_{1,96}=33.686, \mathrm{p}<0.001$ ). Significant differences were also observed between regions in the RNA content vs age relationship (ANCOVA, $\mathrm{F}_{2,131}=39.599, \mathrm{p}<0.001$ ). The RNA content of the Bay of Almería larvae was also significantly higher than those from the Bay of Málaga (ANCOVA, $\mathrm{F}_{1,96}=26.68, \mathrm{p}<0.001$ ).

In respect to the PROT content vs age relationship, the Ebro population showed a significantly higher PROT content with age (ANCOVA, $\mathrm{F}_{2,125}=14.92, \mathrm{p}<0.001$ ), but the Alborán Sea populations did not show significant differences between the Bay of Almería and Bay of Malaga sardine larval populations (ANCOVA, $\mathrm{F}_{1,91}=0.4882, \mathrm{p}>0.05$ ).

Regarding carbohydrates $(\mathrm{CHO})$, the Bay of Almería larvae showed a significantly higher $\mathrm{CHO}$ content with age (ANCOVA, $F_{2,127}=97.322$, $\mathrm{p}<0.0001)$ than the Ebro and Bay of Málaga larvae, which also showed significant differences between them (ANCOVA, $\mathrm{F}_{1,82}=56.637, \mathrm{p}<0.0001$ ).

With respect to the otolith radius (OR) vs age relationship, the Ebro population showed a significantly higher otolith growth (ANCOVA, $\left.\mathrm{F}_{2,154}=32.931, \mathrm{p}<0.001\right)$ than the Bay of Almería and Bay of Málaga populations. The latter also showed significant differences between them, with signifi-

TABLE 4. - ANCOVA analysis results from the comparison of somatic and otolith growth relationships with age between sardine larval populations. Symbols represent low $(\bullet)$, higher $(\uparrow)$ and significantly highest values $(\Uparrow) ;(\mathrm{p}<0.001)$.

\begin{tabular}{lccccccc}
\hline & LS & OTO & DW & DNA & RNA & PROT & CHO \\
\hline Ebro & $\Uparrow$ & $\Uparrow$ & $\Uparrow$ & $\Uparrow$ & $\Uparrow$ & $\Uparrow$ & $\uparrow$ \\
Almería & $\uparrow$ & $\uparrow$ & $\uparrow$ & $\uparrow$ & $\uparrow$ & $\uparrow$ & $\Uparrow$ \\
Málaga & $\bullet$ & $\bullet$ & $\bullet$ & $\bullet$ & $\bullet$ & $\bullet$ & $\bullet$ \\
\hline
\end{tabular}

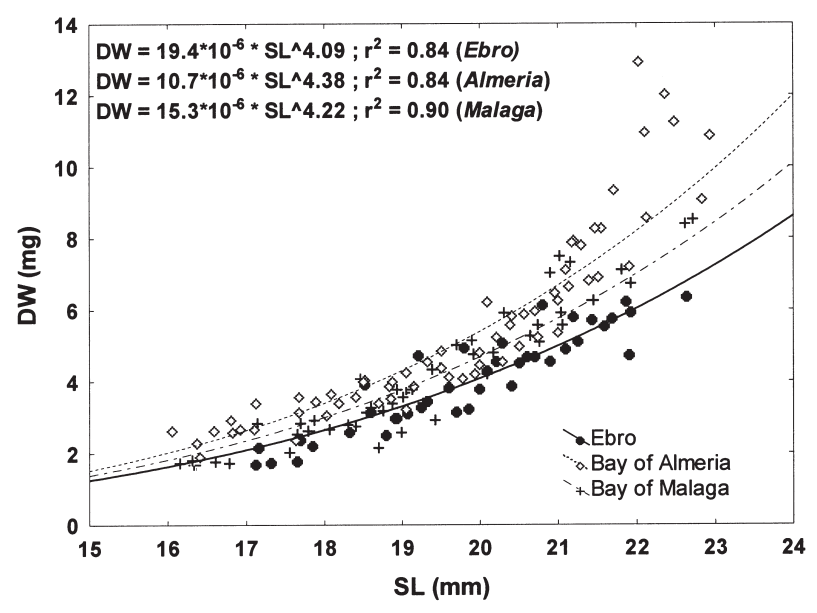

FIG. 7. - DW vs SL relationship of each sardine larval population at the sampled sites.

cantly higher otolith growth in the Bay of Almería population (ANCOVA, $\mathrm{F}_{1,115}=11.266, \mathrm{p}<0.01$ ). The average increment widths of each larval population are shown in Figure 6. Significantly greater increment widths were found in the Ebro River population, followed by that of the Bay of Almería, which also showed significantly wider increments than the Bay of Málaga population (ANCOVA, $\mathrm{F}_{2,105}=$ 30.347, $\mathrm{p}<0.001)$.

Table 4 sums up the somatic and otolith growth comparisons and their ensuing significance levels. All the growth parameters analysed show the higher larval growth potential of the Ebro population.

\section{Relative growth}

The DW to SL power relationship of each larval population is shown in Figure 7. Significant differences (ANCOVA, $\mathrm{F}_{2,143}=62.85, \mathrm{p}<0.001$ ) were observed among all the sampled populations. Both Alborán Sea populations showed greater DW vs SL than the Ebro population. The Bay of Almería population showed significantly higher DW vs SL (ANCOVA, $\mathrm{F}_{1,104}=40.133, \mathrm{p}<0.001$ ) than the Bay of Málaga population, even when larvae from the Almería population beyond $10 \mathrm{mg}$ were excluded from the statistical analysis.

The power relationship between SL and OR is shown in Figure 8. The Ebro population showed significantly smaller otoliths in relation to SL (ANCOVA, $\left.\mathrm{F}_{2,139}=53.016, \mathrm{p}<0.001\right)$ than the populations sampled in the Alborán Sea, while no significant differences were observed between the Bay of Almería and Bay of Málaga populations (ANCOVA, $\left.\mathrm{F}_{1,103}=2.3178, \mathrm{p}>0.05\right)$. 


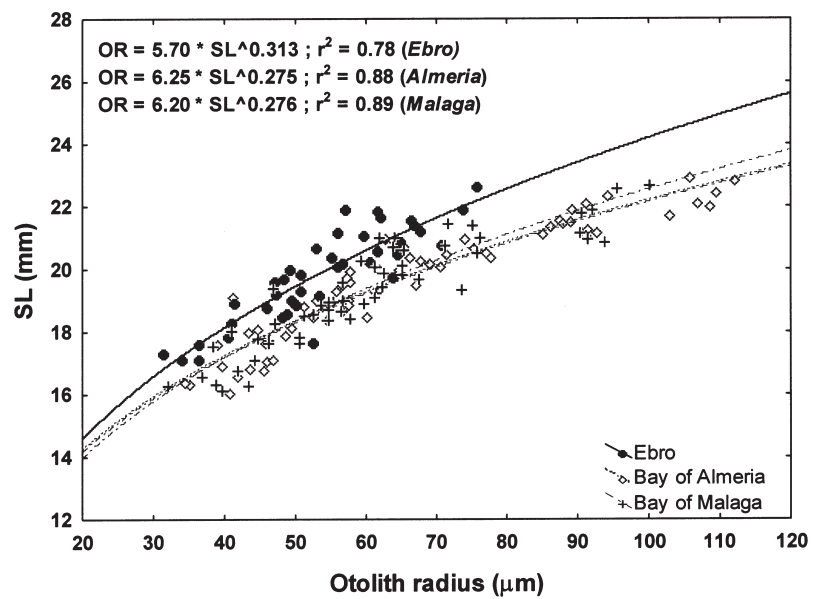

FIG. 8. - SL vs OR relationship of each sardine larval population at the sampled sites.

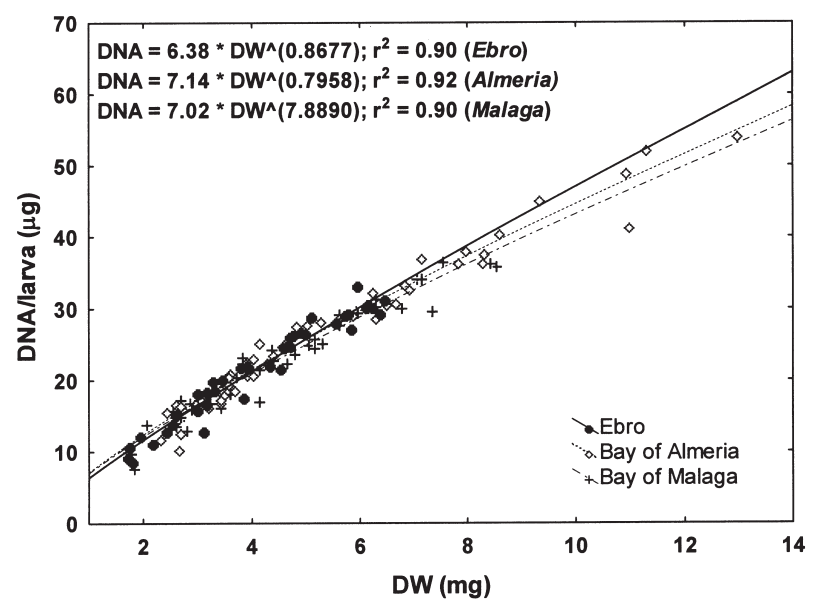

FIG. 9. - DNA content vs DW relationship of each sardine larval population at the sampled sites.

The Alborán Sea populations, particularly those from the Bay of Almería, showed significantly greater DNA content for a given SL than the Ebro and the Bay of Málaga populations (ANCOVA, $\left.\mathrm{F}_{2,135}=51.229, \mathrm{p}<0.001\right)$ (Table 5). Furthermore, the Bay of Málaga population also showed a significantly greater amount of DNA than the Ebro population (ANCOVA, $\mathrm{F}_{1,86}=14.826, \mathrm{p}<0.001$ ).

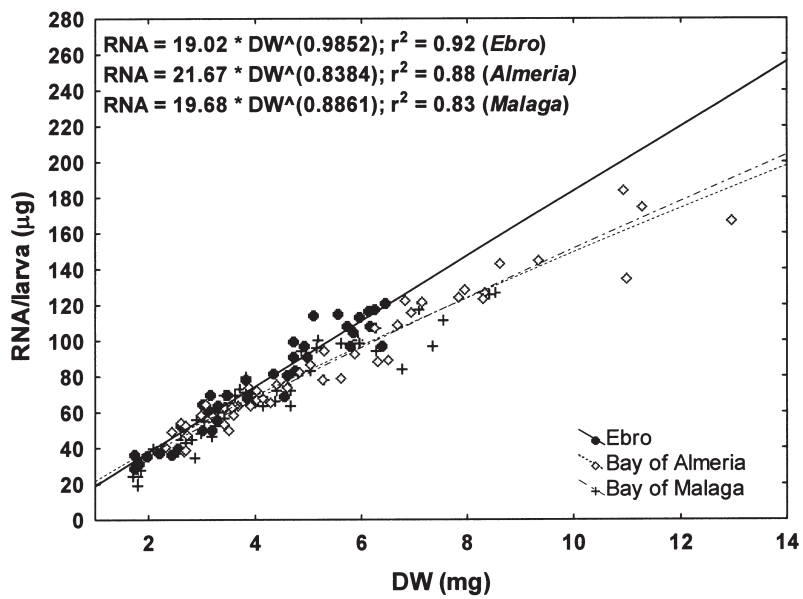

FIG. 10. - RNA content vs DW relationship of each sardine larval population at the sampled sites.

However, DNA content by DW did not show significant differences between the three larval populations (ANCOVA, $\mathrm{F}_{2,135}=0.4368, \mathrm{p}>0.05$ ) (Fig. 9).

RNA had a significantly higher content with larval size (SL) in the Bay of Almería population (ANCO$\mathrm{VA}, \mathrm{F}_{2,135}=24.078, \mathrm{p}<0.0001$ ), while no significant differences (ANCOVA, $\mathrm{F}_{1,86}=1.041, \mathrm{p}>0.05$ ) were observed between the Ebro and Bay of Málaga populations (Table 5). With respect to the RNA relationship with DW, the Ebro population showed a significantly higher RNA content than the Bay of Almería and Bay of Málaga populations (Fig. 10) (ANCOVA, $\mathrm{F}_{2,135}=11.198, \mathrm{P}<0.001$ ), while no significant differences were observed between these last two populations (ANCOVA, $\mathrm{F}_{1,97}=1.5387, \mathrm{p}>0.05$ ).

PROT content also showed significantly higher values with SL in the Alborán Sea population than in the Ebro population (ANCOVA, $F_{2,128}=4.9107$, $\mathrm{p}<0.01)$. The Alborán Sea populations did not show significant differences between them (Table 5) (ANCOVA, $\mathrm{F}_{1,92}=0.0415, \mathrm{p}>0.05$ ). The PROT vs DW relationship showed significantly higher PROT content in the Ebro and Bay of Málaga populations than in the Bay of Almería population (ANCOVA,

TABLE 5. - Relative growth of DNA, RNA, PROT and CHO content in relation to SL by site of each sardine larval population.

\begin{tabular}{|c|c|c|c|}
\hline Variable & Ebro & $\begin{array}{l}\text { Somatic growth vs SL } \\
\text { Almería }\end{array}$ & Málaga \\
\hline DNA $(\mu \mathrm{g})$ & $\begin{array}{l}\mathrm{DNA}=(0.279 \mathrm{e}-3) * \mathrm{SL}^{\wedge}(3.754) \\
\mathrm{r}^{2}=0.84\end{array}$ & $\begin{array}{l}\mathrm{DNA}=(0.109 \mathrm{e}-3) * \mathrm{SL}^{\wedge}(4.151) \\
\mathrm{r}^{2}=0.91\end{array}$ & $\begin{array}{l}\text { DNA }=(0.336 \mathrm{e}-3) * \mathrm{SL}^{\wedge}(3.727) \\
\mathrm{r}^{2}=0.85\end{array}$ \\
\hline RNA $(\mu \mathrm{g})$ & $\begin{array}{l}\text { RNA }=(0.335 \mathrm{e}-3) * \mathrm{SL}^{\wedge}(4.11) \\
\mathrm{r}^{2}=0.77\end{array}$ & $\begin{array}{l}\text { RNA }=(0.126 \mathrm{e}-3) * \mathrm{SL}^{\wedge}(4.494) \\
\mathrm{r}^{2}=0.90\end{array}$ & $\begin{array}{l}\mathrm{RNA}=(0.314 \mathrm{e}-3) * \mathrm{SL}^{\wedge}(4.143) \\
\mathrm{r}^{2}=0.81\end{array}$ \\
\hline PROT $(\mu \mathrm{g})$ & $\begin{array}{l}\mathrm{PROT}=0.020509 * \mathrm{SL} \wedge(3.684) \\
\mathrm{r}^{2}=0.63\end{array}$ & $\begin{array}{l}\mathrm{PROT}=0.002534 * \mathrm{SL} \wedge(4.423) \\
\mathrm{r}^{2}=0.79\end{array}$ & $\begin{array}{l}\mathrm{PROT}=0.03877 * \mathrm{SL} \wedge(3.515) \\
\mathrm{r}^{2}=0.62\end{array}$ \\
\hline $\mathrm{CHO}(\mu \mathrm{g})$ & $\begin{array}{l}\mathrm{CHO}=(0.578 \mathrm{e}-5) * \mathrm{SL}^{\wedge}(3.251) \\
\mathrm{r}^{2}=0.75\end{array}$ & $\begin{array}{l}\mathrm{CHO}=(0.415 \mathrm{e}-4) * \mathrm{SL}^{\wedge}(2.814) \\
\mathrm{r}^{2}=0.73\end{array}$ & $\begin{array}{l}\mathrm{CHO}=(0.813 \mathrm{e}-6) * \mathrm{SL}^{\wedge}(3.927) \\
\mathrm{r}^{2}=0.72\end{array}$ \\
\hline
\end{tabular}




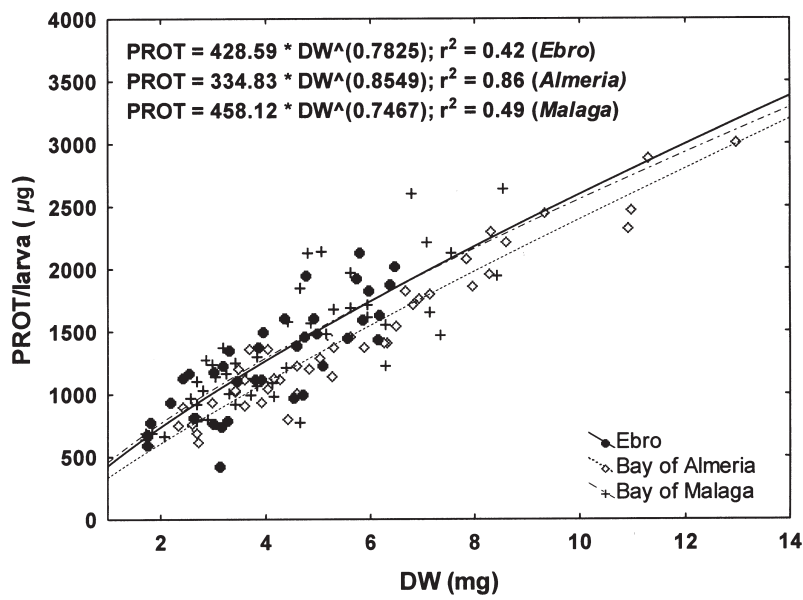

FIG. 11. - PROT content vs DW relationship of each sardine larval population at the sampled sites.

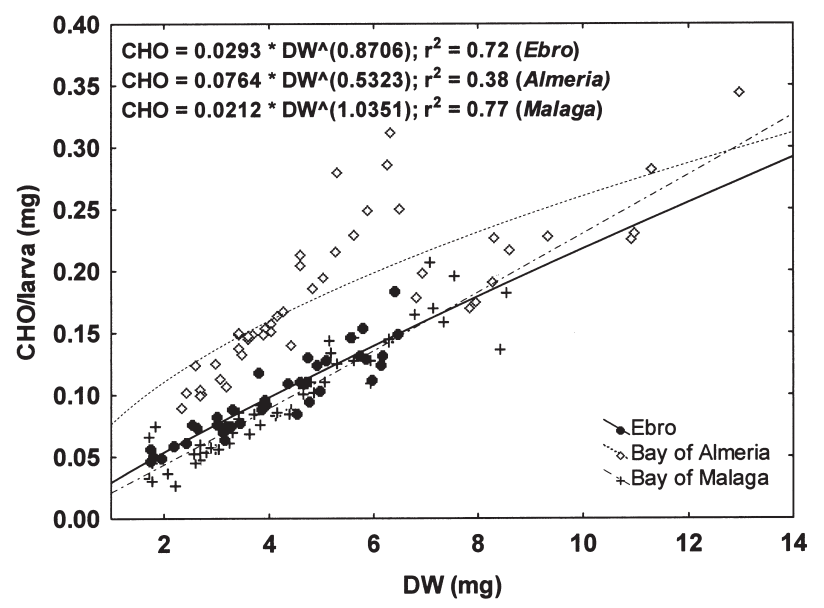

FIG. 12. - CHO content vs DW relationship of each sardine larval population at the sampled sites.

$\left.\mathrm{F}_{2,128}=5.5285, \mathrm{p}<0.005\right)$ (Fig. 11). No significant differences were observed between the Ebro and Bay of Málaga populations (ANCOVA, $\mathrm{F}_{1,84}=0.1488$, $\mathrm{p}>0.05$ ).

With respect to the relationship of SL and the amount of CHO (Table 5), the Bay of Almería population showed a significantly greater amount of CHO (ANCOVA, $\mathrm{F}_{2,131}=138.33$, $\mathrm{p}<0.001$ ) with larval size, while the Bay of Málaga and Ebro populations did not show significant differences between them (ANCOVA, $\mathrm{F}_{1,86}=0.1775, \mathrm{p}>0.05$ ). The rela-
TABLE 7. Basic statistics of the RNA/DNA ratios by larval sardine sampled sites off the Mediterranean coast.

\begin{tabular}{lccccc}
\hline & \multicolumn{5}{c}{ RNA/DNA ratios } \\
Site & Mean & MIN & MAX & ST. DEV. & N \\
\hline Ebro & 3.510 & 2.7053 & 4.763 & 0.4192 & 39 \\
Almería & 3.262 & 2.7219 & 3.767 & 0.2689 & 50 \\
Málaga & 3.188 & 2.0281 & 4.311 & 0.4770 & 50 \\
\hline
\end{tabular}

tionship of CHO vs DW showed significant differences among all the populations sampled (ANCOVA, $\mathrm{F}_{2,131}=94.634, \mathrm{p}<0.001$ ) (Fig. 12). The highest $\mathrm{CHO}$ content corresponded to the Bay of Almería populations, whereas the lowest corresponded to the Málaga population.

Table 6 summarises the comparative relative growth analysis and the resulting significance levels of the different larval population comparisons.

\section{Nutritional condition}

RNA/DNA ratios with size did not show an increasing trend with SL in the late larval stages of sardine. Although the highest values were observed in the Ebro larval population, the average RNA/DNA ratio did not show significant differ-

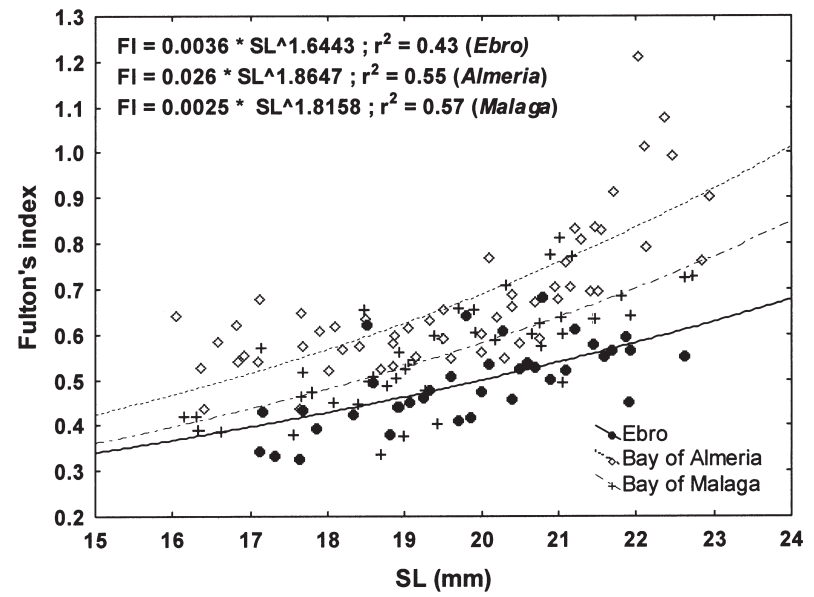

FIG. 13. - Fulton index vs SL relationship of each sardine larval population off the sampled sites.

TABLE 6. - ANCOVA analysis results in relation to relative growth relationships between sardine larval populations. Symbols represent low $(\diamond)$, higher $(\uparrow)$ and significantly highest values $(\Uparrow)(\mathrm{p}<0.001)$, and $(=)$ non-significant difference $(\mathrm{p}>0.05)$.

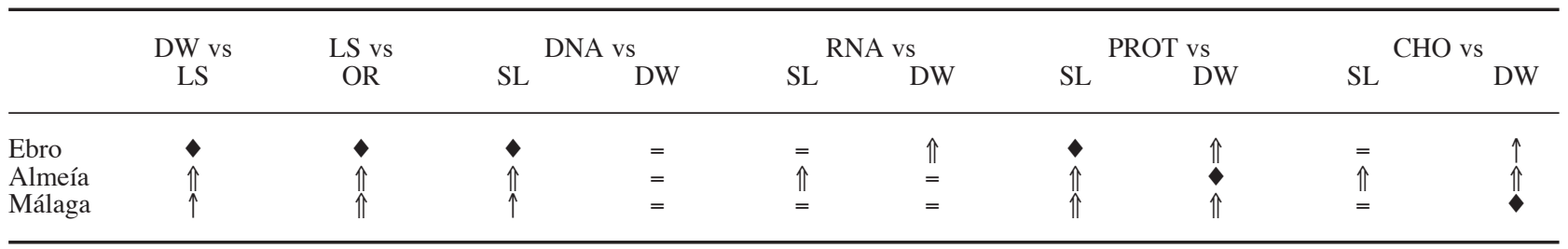


ences between the populations, ranging from a maximum of 3.5 in the Ebro population to a minimum of 3.18 in the Bay of Málaga population (Table 7).

Fulton's condition factor showed potential relationships with SL (Fig. 13). Significant differences among all the sampled larval populations were observed (ANCOVA, $\mathrm{F}_{2,139}=61.749$, $\mathrm{p}<0.001$ ), with the Bay of Almería population showing the highest Fulton's condition factor, and the Ebro population showing the lowest.

\section{DISCUSSION}

From the SL vs age relationship standpoint, there was a clear increase in SL with age in the Ebro river population, which may account for as much as a 2 $\mathrm{mm}$ difference between this population and those from the Alborán Sea. The Ebro sardine SL growth potential is linked to its DW growth potential (see Table 4), and consequently with its greater otolith growth manifested by its greater increment width deposition (Fig. 6). Since the biochemical composition of larvae constitutes proxies of somatic mass, the greater Ebro larval growth potential is concordant with the differences observed in the DNA, RNA and PROT content with age (see Tables 3 and 4). Among all the biochemical constituents, only $\mathrm{CHO}$ content showed a significantly greater increase with age in the larvae from the Bay of Almería than in those from the Ebro.

However, the faster growth rates of the Ebro population did not lead to a greater DW vs SL relationship, since both Alborán Sea populations showed higher DW vs SL (see Table 6), in conformity with a similar trend followed by the DNA vs SL relationship (Table 4). Bearing in mind that the mean SL of each larval population is quite similar (19.7-20.0 $\mathrm{mm}$ ), and that a temporal lapse difference of 5 days may occur for the slower growing Alborán Sea populations to attain their average SL, larval growth may be favouring somatic mass growth rather than somatic length, thereby compensating their lower growth potential. The temporal difference between the slow and fast growing populations could also account for the larger OR for a given SL found in the Alborán Sea larvae, due to a greater number of increments being deposited.

A different pattern is observed when analysing the relative growth of biochemical constituents with DW. DNA vs DW did not show significant differ- ences between the sampled populations, thus indicating that for a given DW the same number of cells is expected. However, RNA content, responsible for PROT synthesis, was significantly higher in relation to DW in the Ebro larvae, and therefore PROT content also showed a greater relation to DW as a result of their higher growth potential in comparison with the Alborán Sea larvae.

In the $\mathrm{CHO}$ vs DW relationship, the Bay of Almería population showed a significantly higher content than the Ebro and Bay of Málaga sardine larvae. Although the overall microzooplankton biomass values did not show significant differences between the sampled sites due to their high variability, the lower PROT content found in the microzooplankton in the Bay of Almería (see Fig. 3) may indicate that larvae tend to prey on other available resources with greater $\mathrm{CHO}$ content. Although, most studies on larval sardine feeding have found that copepod nauplii and copepodites constitute a large part of their diet (Conway et al., 1994), other investigations have found that sardine larvae may prey on phytoplanktonic communities, as observed in the highly productive region of the Gulf of Lions (Rasoanarivo et al., 1991).

In many fish species $\mathrm{CHO}$ represents an important food reserve that may be drawn from phytoplankton. Herbivorous fish metabolise carbohydrates better than carnivorous species (Cowey and Sargent, 1979; Furuichi and Yone, 1982). Habib et al. (1994) reported as much as a $30 \%$ high dietary requirement of carbohydrates inducing maximum growth in silver barb, complying with its herbivorous nature.

The differences observed in larval growth potential between the Ebro and Alborán Sea populations may be attributed to food availability. The Ebro river mouth area, reported to be an important sardine spawning ground (Olivar et al., 2001), showed greater potential feeding availability (see Fig. 3), made evident by the highest microzooplankton DW values observed, and the respective PROT and $\mathrm{CHO}$ contents.

Another factor that may influence larval growth is temperature. However, the small difference in temperature (below $1^{\circ} \mathrm{C}$, see Table 2) cannot be held accountable for the varying larval growth strategies of the sardines collected at different Mediterranean sites. Likewise, since temperature may influence RNA/DNA ratios (Buckley, 1982; Goolish et al., 1984; Ferguson and Danzmann, 1990), the observed 
temperature difference in this study allows a direct comparison of the RNA/DNA ratios between the larval populations. Although the average RNA/DNA ratios of each sardine larval population did not show significant differences, the Ebro population showed the highest RNA/DNA ratios (see Table 7). Nevertheless, all the larval populations of this study cannot be considered to be undernourished, as the point of no return reported for this species is 1.3 (Chicharo, 1997), similar to that reported for the Japanese sardine (Kimura et al., 2000).

The observations of this study show differences in sardine larval growth attributed to particular conditions of the surrounding environment, as found in other fish larvae (Clemmesen et al., 1997; Kimura et al., 2000; Chicharo et al., 2003; RossiWongtschowski et al., 2003; Catalán et al., 2006). The slower somatic growth observed in the Alborán Sea sardine populations may respond to differences in the larval food resources available. The relative growth of the otoliths of sardine originating in these Alborán Sea sites did not show significant differences between the Bay of Almería and Bay of Málaga larvae, thereby indicating their similar growth characteristics. However, a significant difference was observed in their DW growth in favour of the Almería population, which therefore has an effect on the higher allometric relationship of DW vs SL of this population (see Figs. 5 and 7). Given that no differences are observed in the amount of DNA with respect to DW, the greater weight of the Almería sardine larvae may be attributed to a greater assimilation of $\mathrm{CHO}$. The accumulation of $\mathrm{CHO}$ in larvae must be a consequence of changes in the feeding regime as larvae sampled in the Bay of Málaga during 2000 and 2001 showed highly contrasting differences between these years (Cortés IEO, unpublished data).

The slower growth strategy of sardine larvae in the Alborán Sea may be caused by the varying environmental processes inducing productivity off its coasts. One of the main sources of environmental variability has its origin in pulses of wind-induced productivity due to the ponientes wind regime (Bosc et al., 2004; Bakun and Agostini, 2001). A study on the Alborán Sea sardine juveniles originating from the sardine larval cohorts of this study (Alemany et al., 2006) shows that otolith increments undergo a periodic decrease in width which is apparently linked to major southern and levantine wind events, whereas during north and northwestern wind events, which are responsible for coastal upwellings in the Alborán Sea, daily ring widths increase progressively. This pattern is made evident in the average increment width evolution of the Alborán Sea sardine larvae (Fig. 6).

In the evolution of daily ring widths with age in the Bay of Almería and Bay of Málaga populations (Fig. 6), two practically synchronous slow growth periods can be observed: the first from increments 20 to 24 and the second from increment 32 onwards. Taking into account the mean birthdate of such specimens, these "slow growth" periods coincided in time with levantine wind episodes, a short one between 13 and 17 December and a second, more important one, which started on 23 December and lasted till 15 January (Alemany et al., 2006). It therefore seems reasonable to infer that the daily growth of the Alborán Sea sardine follows a series of pulses of increased and diminished growth rates responding to the environmental wind-induced changes.

As a result, the slow-growing larvae of the Alborán Sea must rely on necessary energy reserves to maintain their growth by pulsations. The significantly higher Fulton's index in the Alborán Sea populations in comparison with the Ebro populations supports this hypothesis. This index indicates the amount of energy reserve in an individual. In the event of diminished feeding resources, the amount of energy storage determines the time span of recovery to its normal status. According to Bosc et al. (2004), the Alborán Sea has the most chaotic cycle of phytoplankton biomass in the western Mediterranean basin, thereby producing the most variability. Thus, the larvae from the Bays of Almería and Málaga could be showing a strategy of energy storage that would allow them to face periods of low productivity. This would explain the high variability observed in the evolution of larval and early juvenile stage growth rates (Alemany et al., 2006), seemingly linked to the alternation of pulses of north and northwestern wind regimes, which would have a positive effect on growth, and southern and levantine winds, which would slow down such growth rates.

\section{ACKNOWLEDGEMENTS}

This work was carried out in the framework of the SAVOR project (CICYT REN2002-04205-C04- 
03/MAR), whose main objective is to define the Optimal Environmental Windows (OEW) that limits the survival of small pelagic species in their early life stages.

\section{REFERENCES}

Abad, R., J. Miquel, M. Iglesias and F. Álvarez. - 1998. Acoustic estimation of abundance and distribution of sardine in the NW Mediterranean. Fish. Res., 34: 239-245.

Alemany, F., I. Álvarez, A. García, D. Cortés, T. Ramírez, J. Quintanilla and J.M. Rodríguez. - 2006. Postflexion larvae and juvenile daily growth patterns of the Alboran Sea sardine (Sardina pilchardus Walb.): influence of wind. Sci Mar., 70S2: 93-104.

Andersen, T. and E. Moksness. - 1988. Manual for reading daily increments by the use of a computer program. Flodevigen Meldingen 4. Directorate of Fisheries. Flodevigen Biological Station. Arendal.

Anderson, J.T. - 1988. A review of size dependent survival during pre-recruit stages of fishes in relation to recruitment. $J$. Northwest Atl. Fish. Sci., 8: 55-66.

Bakun, A., and V.N. Agostini. - 2001. Seasonal patterns of windinduced upwelling/downwelling in the Mediterranean Sea. Sci. Mar., 65(3): 243-257.

Belchier, M., C. Clemmesen, D. Cortés, T. Doan, A. Folkvord, A. García, A. Geffen, H. Høie, A. Johannessen, E. Moksness, H. de Pontual, T. Rámirez, D. Schnack and B. Sveinsbo. - 2004. Recruitment studies: Manual on precision and accuracy of tools. ICES Tech. Mar. Environ. Sci., 33: 35 pp.

Bosc, E., A. Bricaud and D. Antoine. - 2004. Seasonal and interannual variability in algal biomass and primary production in the Mediterranean Sea, as derived from 4 years of SeaWiFS observations, Global Biogeochem. Cycles, 18 (1), [n/p].

Bradford, M.J. - 1992. Precision of recruitment predictions from early life stages of marine fishes. Fish. Bull., 90 (3): 439-453.

Buckley, L.J. - 1982. Effects of temperature on growth and biochemical composition of larval winter flounder Pseudopleuronectes americanus. Mar. Ecol. Prog. Ser., 8: 181-186.

Butler, J.L.. - 1991. Mortality and recruitment of Pacific sardine, Sardinops sagax caerulea, larvae in the California Current. Can. J. Fish. Aquat. Sci., 48(9): 1713-1723.

Castellón, A., J. Font and E. García. - 1990. The Liguro-ProvenzalCatalán current (NW Mediterranean) observed by Doppler profiling in the Balearic Sea. Sci. Mar., 54(3) : 269-276.

Catalán, I.A., M. P. Olivar, I. Palomera and E. Berdalet. - 2006. Link between environmental anomalies, growth and condition of pilchard Sardina pilchardus larvae in the northwestern Mediterranean. Mar. Ecol. Progr. Ser., 307: 219-231.

Chicharo, M.A. - 1997. Starvation percentages in field caught Sardina pilchardus larvae off southern Portugal. Sci. Mar., 61(4): 507-516

Chicharo, M.A., E. Esteves, A.M.P. Santos, A. dos Santos, A. Peliz and P. Re. - 2003. Are sardine larvae caught off northern Portugal in winter starving? An approach examining nutritional condition. Mar. Ecol. Prog. Ser., 257: 303-309.

Conway, D.V.P., S.H. Coombs, M.L. Fernandez de Puelles and P.R.G. Tranter. - 1994. Feeding of larval sardine, Sardina pilchardus (Walbaum), off the north coast of Spain. Bol. Inst. Esp. de Oceanogr., 10(2): 165-175.

Cowey, C.B. and J.R. Sargent. - 1979. Nutrition. In: W.S. Hoar, D.J. Randall and J.R. Brett (eds.), Fish Physiology, pp. 1-69. Academic Press, New York.

Clemmesen, C., R. Sanchez and C. Wongtshowski. - 1997. A regional comparison of the nutritional condition of SW Atlantic anchovy larvae, Engraulis anchoita, based on RNA/DNA ratios. Arch. Fish. Mar. Res., 45(1): 17-43.

Dubois, M., K.A. Gilles, J.K. Hamilton and F. Smith. - 1956. Colorimetric method for determination of sugars and related substances. Anal. Chem., 28: 350-356.

Estrada, M. - 1996. Primary production in the northwestern Mediterranean. Sci. Mar., 60(Suppl. 2): 55-64.

Fage, L. -1920. Engraulidae, Clupeidae. Report on the Danish
Oceanographical Expeditions 1908-1919 to the Mediterranean and adjacent seas, 2(6), $140 \mathrm{pp}$.

Ferguson, M.M. and R.G. Danzmann. - 1990. RNA:DNA ratios in white muscle as estimates of growth in rainbow trout held at different temperatures. Can. J. Zool., 68: 1494-1498.

Folkvord, A. and J.R. Hunter. - 1986. Size specific vulnerability of northern anchovy (Engraulis mordax) larvae to predation by fishes. Fish. Bull., 84: 859-869.

Font, J., J. Salat and J. Tintoré. - 1988. Permanent features of the circulation in the Catalán Sea. In: H.J. Minas and P. Nival, (eds.), Pelagic Mediterranean Oceanography. Oceanol. Acta, 9: 51-57.

Font, J., J. Salat and A. Julià. - 1990. Marine circulation along the Ebro continental margin. Marine Geology, 95 (3-4): 165-177.

Furuichi, M. and Y. Yone. - 1982. Availability of carbohydrates in nutrition of carp and Red Sea bream. Bull. Jap. Soc. Sci. Fish., 48: 945-948.

García, A., D. Cortés, T. Ramírez, A. Giráldez and A. Carpena. 2003. Contribution of larval growth rate variability to the recruitment of the Bay of Málaga anchovy (SW Mediterranean) during 2000-2001 spawning seasons. Sci. Mar., 67(4): 477-490.

García, A., J. Crespo and J.D. Rey. - 1981. A contribution to the knowledge of the southern part of Spain's Mediterranean coastal zone including a description of a beach seine fishery. FAO-CGPM, Etudes et Revues, 58: 139-155.

García, A., J. Pérez de Rubín and J.M Rodríguez. - 1988. La distribución de las áreas de puesta de la sardina (Sardina pilchardus (Walb.) en el sector noroccidental costero del Mar de Alboran en marzo de 1982. Inf. Téc. Inst. Esp. Oceanogr., 56: $1-24$.

García-Gorritz, E. and M.E. Carr. - 2001. Physical control of phytoplankton distributions in the Alborán Sea: a numerical and satellite approach. J. Geophys. Res., 106(C8): 16795-16805.

Gómez-Larrañeta, M. - 1960. Synopsis of biological data on Sardina pilchardus of the Mediterranean and adjacent seas. FAO Fisheries Biology Synopsis, 9: 137-173.

Goolish, E.M., M,G. Barron and I.R Adelman. - 1984. Thermoacclimatory and response of nucleic acid and protein content of carp muscle tissue: influence of growth rate and relationship to glycine uptake by scales. Can. J. Zool., 62: 2164-2170.

Habib, M.A.B, M.R. Hasan and A.M. Akland. - 1994. Dietary carbohydrate utilization by silver barb (Pontius gonionotus. In: S.S. De Silva (ed.), Asian Fish. Soc. Spec. Publ. Asian Fisheries Society, 57-62. Manila, Phillipines.

Hare J.A. and R.K. Cowen. - 1997. Size, growth, development, and survival of the planktonic larvae of Pomatomus saltatrix (Pisces: Pomatomidae). Ecology 78: 2415-2431.

Høie, H., A. Folkvord and A. Johannessen. - 1999. The influence of different parental combinations and incubation temperature on the RNA and DNA content of herring larvae at hatching: a pilot study. J. Fish Biol., 55(A): 110-118.

Houde, E.D. - 1987. Fish early life dynamics and recruitment variability. Am. Fish. Soc. Symp. 2: 17-29.

Kimura, R., Y. Watanabe and H. Zenitani. - 2000. Nutritional condition of first-feeding larvae of Japanese sardine in the coastal waters along the Kuroshio Current. ICES J. Mar. Sci., 57: $240-248$

Kishida, T., Y. Katsumata, M. Nakamura, S. Yanagibashi and S. Funakoshi. - 1994. An attempt for assessment on relative abundance of shirasu, larval Japanese sardine, off the Pacific coast of Japan. Bull. Natl. Res. Inst. Fish. Sci., 6: 57-66.

Lloret, J., I. Palomera, J. Salat and I. Sole. - 2004. Impact of freshwater input and wind on landings of anchovy (Engraulis encrasicolus) and sardine (Sardina pilchardus) in shelf waters surrounding the Ebre (Ebro) River delta (north-western Mediterranean). Fish. Oceanogr. 13(2): 102-110.

Lowry O.H., N.J. Rosenbraugh, A.L. Farr and R.J. Randall. - 1951 Protein measurements with the Folin phenol reagent. J. Biol. Chem., 193: 256-275.

Miller T.J., L.B. Crowder, J.A. Rice and E.A. Marschall. - 1988 Larval size and recruitment mechanisms in fishes: toward a conceptual framework. Can. J. Fish. Aquat. Sci., 45: 1657-1670.

Millot, C., 1990. - The Gulf of Lions hydrodynamics. Cont. Shelf Res., 10(9-11): 885-894.

Olivar, P., J. Salat and I. Palomera. - 2001. Comparative study of the spatial distribution patterns of the early stages of anchovy and pilchard in the NW Mediterranean Sea. Mar. Ecol. Progr. 
Ser, 217: 111-120.

Olivar, P., I.A. Catalán, M. Emelianov and M.L. Fernández de Puelles. -2003. Early stages of Sardina pilchardus and environmental anomalies in the Northwestern Mediterranean. Estuar. Coast. Shelf Sci., 56: 609-619.

Palomera, I. and P. Olivar. - 1996. Nearshore ichthyoplankton off the Costa Brava (Northwest Mediterranean). Bol. Inst. Esp. Oceanog., 22: 71-76.

Peterman, R.M., M.J. Bradford, N.C.H. Lo, and R.D. Methot. 1988. Contribution of early life stages to interannual variability in recruitment of northern anchovy (Engraulis mordax). Can. $J$. Fish. Aquat. Sci., 45: 8-16.

Rámirez, T., D. Cortés and A. García. - 2001. Growth of North Alborán Sea sardine estimated by otolith microstructure, nucleic acids and protein content. J. Fish Biol., 59: 403-415.

Ré, P. - 1986. Otolith microstructure and the detection of life history events in sardine and anchovy larvae. Ciênc. Biol. Ecol. Sist., 6 (1/2): 9-17.

Rao, N.I. and G. Krupanidhi. - 2001. Biochemical composition of zooplankton from the Andaman Sea. J. mar. biol. Ass. India, 43 (1-2): 49-56.

Rao, N.I. and R.R. Kumari. - 2002. Biochemical composition of zooplankton from Visakhapatnam harbour waters, east coast of India. Indian J. Mar. Sci., 31(2): 125-129.

Rasoanarivo, R., J. Folack, G. Champalbert and B. Becker. - 1991 Relations entre les communautes phytoplanctoniques et l'alimentation des larves de Sardina pilchardus Walb. dans le golfe de Fos (Mediterranee occidentale): Influence de la lumiere sur l'activite alimentaire des larves. J. Exper. Mar. Biol. Ecol., 151(1): 83-92.

Rodríguez, J.M. - 1990. Contribución al conocimiento del ictioplancton del mar de Alborán. Bol. Inst. Esp. Oceanogr., 6: 1-20.
Romanelli, M., O. Giovanardi, E. Tarulli and L. Manzueto. - 1994. Analisi quali-quantitativa del prodotto commerciale derivante dalla pesca del 'bianchetto' nel compartimento marittimo di Crotone (Mar Ionio). Biol. Mar. Mediterr., 1(1): 301-302.

Romanelli, M., F. Colloca, L. Manzueto, M. Manca, R. Germano and O. Giovanardi. - 1998. Analisi delle catture ottenute in campionamenti svolti con una sciabica da "bianchetto" nell'area di Sestri Levante (Liguria orientale). Biol. Mar. Mediterr. 5(1): 718-720.

Rossi-Wongtschowski, C.L.D.B., C. Clemmesen, B. Ueberschaer and J.F. Dias. 2003. Larval condition and growth of Sardinella brasiliensis (Steindachner, 1879): preliminary results from laboratory studies. Sci. Mar., 67(1): 13-23.

Salat, J., M. García, A. Cruzado, A. Palanques, L. Arín, D. Gomis, J. Guillén, A. de León, J. Puigdefábregas, J. Sospedra and Z.R. Velásques. - 2002. Seasonal changes of water mass structure and shelf slope exchanges at the Ebro shelf (NW Mediterranean). Cont. Shelf Res., 22: 327-346.

Sarhan, T., J. García-Lafuente, M. Vargas, J.M. Vargas and F. Plaza. - 2000. Upwelling mechanisms in the northwestern Alborán Sea. J. Mar. Syst., 23: 317-331.

Suda, M. and T. Kishida. - 1997. The yearly fluctuation of survival indices before and after shirasu, the larval stage, of Japanese sardine from 1979 to 1992 off the Pacific coast of Japan. Fish. Sci., 63(1): 60-63.

Ungaro, N., N. Casavola, G. Marano and E. Rizzi. - 1994. 'Bianchetto' and 'Rossetto' fry fisheries in the Manfredonia Gulf: Effort exerted and catch composition. Oebalia, 20: 99-106.

Received October 26, 2005. Accepted May 26, 2006.

Published online September 28, 2006. 
